\title{
LOW LEVELS OF VITAMIN D WERE ASSOCIATED WITH COAGULOPATHY AMONG HOSPITALIZED CORONAVIRUS DISEASE-19 (COVID-19) PATIENTS: A SINGLE-CENTERED STUDY IN INDONESIA
}

\author{
NISKI NIVOI VITAMINA D POVEZANI SU SA KOAGULOPATIJOM KOD HOSPITALIZOVANIH \\ PACIJENATA SA KORONAVIRUSOM (COVID-19): JEDNOCENTRICNA STUDIJA U INDONEZIJI
}

\author{
Hani Susianti ${ }^{1}$, Cesarius Singgih Wahono ${ }^{2}$, Perdana Aditya Rahman ${ }^{2}$, Mirza Zaka Pratama², \\ Indah Adhita Wulanda ${ }^{1}$, Khoirunisah Dwi Hartanti ${ }^{1}$, Elvira Sari Dewi ${ }^{3}$, Kusworini Handono ${ }^{1}$ \\ ${ }^{1}$ Department of Clinical Pathology, Faculty of Medicine, University of Brawijaya, Malang, Indonesia \\ ${ }^{2}$ Rheumatology and Immunology Division, Department of Internal Medicine, Faculty of Medicine, \\ University of Brawijaya, Malang, Indonesia \\ ${ }^{3}$ Basic Nursing Department, Faculty of Medicine, University of Brawijaya, Malang, Indonesia
}

\section{Summary}

Background: This study was aimed to explore the association of vitamin $D$ in the risk of coagulopathy in coronavirus disease-19 (COVID-19).

Methods: Clinical and laboratory findings were obtained from 50 confirmed COVID-19 patients hospitalized in Saiful Anwar General Hospital, Malang, Indonesia, from September to November 2020. Thrombotic events during hospitalization were recorded, and the ISTH disseminated intravascular coagulation (DIC) score was used to classify overt DIC. Hypovitaminosis D was defined by serum vitamin D level $<49.92 \mathrm{nmol} / \mathrm{L}$.

Results: Among 50 patients, 42 (84\%) had hypovitaminosis D, and 6 (12\%) developed thrombotic events. Vitamin D levels were lower in patients with thrombotic events $(p=0.015), D$-dimer $>2 \mathrm{mg} / \mathrm{L}(p=0.006)$, ISTH DIC score $\geq 5(p=0.020)$, admitted on ICU $(p=0.002)$, and non-survivor groups $(p=0.007)$. Multivariate analysis for the risk in increased D-dimer levels showed low vitamin $D$ as the only significant risk factor with OR 1.8 (1.2-4.4), $p=0.034$ Low vitamin $D$ also increased the risk for developing overt DIC with OR. 5.4 (1.0-30.2), $p=0.039$. Vitamin D level had negative correlations with ferritin $(R=-0.316$, $p=0.044)$ and $\operatorname{CRP}(R=-0.530, p=0.000)$.

\section{Kratak sadržaj}

Uvod: Cilj ove studije je bio da istraži povezanost vitamina $D$ sa rizikom od koagulopatije kod koronavirusne bolesti 2019 (COVID-19).

Metode: Klinički i laboratorijski nalazi dobijeni su od 50 potvrđenih pacijenata sa COVID-19 hospitalizovanih u opštoj bolnici Saiful Anvar u Malangu u Indoneziji, od septembra do novembra 2020. Zabeleženi su trombotični događaji tokom hospitalizacije, a rezultati ISTH diseminovane intravaskularne koagulacije (DIC) korišćeni su za klasifikaciju očigledne DIC. Hipovitaminoza D je definisana nivoom vitamina $D$ u serumu $<49,92 \mathrm{nmol} / \mathrm{L}$.

Rezultati: Od 50 pacijenata, 42 (84\%) je imalo hipovitaminozu D, a 6 (12\%) je razvilo trombotičke događaje. Nivoi vitamina $D$ su bili niži kod pacijenata sa trombotičkim događajima ( $p=0,015)$, D-dimerom $>2 \mathrm{mg} / \mathrm{L}(\mathrm{p}=0,006)$, ISTH DIC rezultatima $\geq 5 \quad(p=0,020)$, primljenih na intenzivnu negu $(p=0,002)$, i grupa koje nisu preživele $(p=0,007)$. Multivarijantna analiza rizika za povećane nivoe $D$-dimera pokazala je nizak nivo vitamina $D$ kao jedini značajni faktor rizika sa OR 1,8 $(1,2-4,4), p=0,034$. Nizak nivo vitamina $D$ je takođe povećao rizik od razvoja očiglednog DIC-a sa OR 5,4 (1,0-30,2), $p=0,039$. Nivo

\footnotetext{
Address for correspondence:

Hani Susianti

Department of Clinical Pathology, Faculty of Medicine University of Brawijaya, Malang, Indonesia Jalan Jaksa Agung Suprapto No.2 Malang, Indonesia Postal address: 65111

Phone: +6281334760295

e-mail: hanisusianti.fk@ub.ac.id
} 
Conclusions: In conclusion, a low level of vitamin D was found in most hospitalized COVID-19 patients and might be associated with the development of coagulopathy.

Keywords: vitamin D, COVID-19, coagulopathy

\section{Introduction}

The novel coronavirus, severe acute respiratory syndrome coronavirus 2 (SARS-Cov-2) emerged first in Wuhan, China, at the end of 2019 and caused pandemic that is still ongoing. It causes a disease called coronavirus disease 2019 (COVID-19) and has affected more than 60 million people worldwide until November 2020 (1). Reported cases of COVID-19 show that this disease ranges from asymptomatic or mild infection to multi-organ failure and death (2). COVID-19 is a systemic disease that affects not only the respiratory tract but also other system organs. Coagulopathy is one of the most common complications reported in several studies, which can be manifested as venous or arterial thromboembolism (3). A marker of a fibrinogen degradation product, $\mathrm{D}$-dimer, also increases in 3.75-68.0\% of COVID-19 patients and elevates the D-dimer level $>2 \mathrm{mg} / \mathrm{L}$ at admission which predicts more severe and higher mortality of the disease $(4,5)$.

International Society of Thrombosis and Hemostasis (ISTH) develops a new guideline for managing coagulopathy in COVID-19. Anticoagulant prophylaxis should be given to all COVID-19 patients with markedly increased coagulation markers, including D-dimer (6). The coagulopathy mechanism in COVID-19 has not been established yet. However, it may overlap with bacteria-induced septic coagulopathy or disseminated intravascular coagulation (DIC). Proinflammatory conditions in COVID-19 through cytokine storm, complement activation, increased damage-associated molecular pattern, and vascular endothelial damage is significant factors that lead to thrombosis $(7,8)$. A previous study also showed that this novel coronavirus could also induce secondary anti-phospholipid syndrome (APS) by promoting the production of anti-phospholipid antibodies (APL-Abs) (9). Xiao et al. (10) also support this study, which found that $47 \%$ of patients with COVID-19 in the intensive unit were positive for APL-Abs. However, it is still unclear whether these antibodies are associated with thrombosis in these patients.

Another novel proposed mechanisms of coagulopathy in COVID-19 is the role of vitamin D in the coagulation system (11). The effect of vitamin $D$ metabolites through vitamin $D$ receptor (VDR) ligands can be attributed to the anti-thrombotic effects. VDR knockout mice have been shown to have a significant association with the presence of thrombosis in several organs (12). Moreover, Khamdevatani et al. (13) vitamina $D$ je imao negativne korelacije sa feritinom $(R=$ $0,316, p=0,044)$ i CRP-om $(R=-0,530, p=0,000)$

Zaključak: Na kraju, kod većine hospitalizovanih pacijenata sa COVID-19 utvrđen je nizak nivo vitamina D koji bi mogao biti povezan sa razvojem koagulopatije.

Ključne reči: vitamin D, COVID-19, koagulopatija

have described that a low level of vitamin $D$ is associated with lower limb deep vein thrombosis (DVT). The role of vitamin $D$ has already been mentioned before in COVID-19 $(14,15)$ but rarely reported in COVID19 coagulopathy. Therefore, this study was aimed to examine the association of serum vitamin $D$ levels in the presence of COVID-19 coagulopathy. This study also compared the role of vitamin $D$ in coagulopathy with other surrogate markers reported previously associated with COVID-19 severity, such as ferritin, lactate dehydrogenase (LDH), neutrophil-lymphocyte ratio (NLR), CRP, and APL-Abs.

\section{Materials and Methods}

\section{Study Design and Participants}

This study was a cross-sectional approach done from September 8 until November 4, 2020. All study participants had a confirmed case of COVID-19 and were hospitalized in Saiful Anwar General Hospital, Malang, Indonesia. A confirmed case was defined according to the case definition provided by WHO with positive results of SARS-Cov-2 from the respiratory specimen by real-time reverse transcription-polymerase chain reaction (RT-PCR) (16). The ethical committee of Saiful Anwar General Hospital, Malang, Indonesia, approved this study (ethical number 400/194/K.3/302/2020). Oral consent was obtained from the patient or their relatives if the patients were unable to communicate. Subjects who got vitamin D supplementation in the last two years were excluded from the study.

\section{Data Collection}

Data were obtained from the patient's medical records, including early signs and symptoms, underlying comorbidities, admission to intensive care unit (ICU), treatment, and outcome of the patient. Thrombotic events were defined as the presence of arterial or venous thromboembolism, such as deep vein thrombosis (DVT), acute coronary syndrome (ACS), cerebrovascular accident (CVA), and pulmonary embolism (PE). The appropriate examination evaluated subjects clinically suspected with thrombotic events to establish the diagnosis (compression ultrasound for DVT, head CT-scan for CVA, electrocardiography (ECG) and cardiac enzyme for ACS ECG, thorax plain radiograph, and $\mathrm{CT}$-scan for $\mathrm{PE}$ ). 
Several routine laboratory examinations also measured at first-time patient admitted to the hospital, including haemoglobin, leukocyte, thrombocyte, prothrombin time (PT), activated partial thromboplastin time (APTT), D-dimer, fibrinogen, lactate dehydrogenase (LDH), alanine aminotransferase, aspartate aminotransferase, urea, and creatinine. Neutrophil lymphocyte ratio (NLR) was measured by the fraction of total neutrophil and lymphocyte count. C-reactive protein (CRP) and ferritin were measured by Chemiluminescent immunoassay (Cobas e411). The anti-phospholipid antibody, including IgM anti-beta2glycoprotein and IgM anti-cardiolipin, were measured by ELISA (Orgentec Diagnostika GmbH). Serum vitamin D (25-Hydroxyvitamin D3) was obtained on the first-day patient admitted and measured by ELISA (Elabscience).

Vitamin $D$ deficiency was defined by serum vitamin D levels below $49.92 \mathrm{nmol} / \mathrm{L}$ (17). The ISTH criteria for DIC were used to assess the probability of overt DIC from the study participants. ISTH DIC scores $\geq 5$ were classified as an overt DIC (18). According to previous research regarding the probability of D-dimer in predicting the COVID-19 prognosis, we also grouped the subjects by D-dimer level. Ddimer $>2 \mathrm{mg} / \mathrm{mL}$ was classified by a higher risk of developing thrombotic events (5).

\section{Statistical Analysis}

Categorical variables were described as frequency rates and percentages. Continuous variables were described using mean, median, and interquartile range (IQR) values. Normally distributed data were compared using a t-test; otherwise, the MannWhitney test was used. The proportion for categorical variables was compared using the chi-square test and the Fisher exact test when data were limited. Bivariate and multivariate logistic regression models were used to explore the risk factor associated with coagulopathy. All statistical analyses were performed using SPSS version 17.0 .

\section{Results}

Clinical and Laboratory Characteristics of the Subjects According to Vitamin D Levels

According to the inclusion and exclusion criteria, 50 COVID-19 patients were included in this study, from September 8 until November 4, 2020. There were 42 patients $(84 \%)$ who had deficient levels of serum vitamin $D(<49.92 \mathrm{nmol} / \mathrm{L})$, while only eight patients $(16 \%)$ had $\geq 49.92 \mathrm{nmol} / \mathrm{L}$. Clinical comparison between the COVID-19 patients with normal to insufficient and deficient vitamin $D$ is shown in Table $I$. Both groups' mean age was similar, with a mean 58.5 \pm 13.5 and $52.5 \pm 14.5$ years old $(p=0.283)$. There was also no statistical difference in sex and comorbidi-
Table I Clinical Characteristics of the Subjects According to Vitamin D Status.

\begin{tabular}{|c|c|c|c|}
\hline & $\begin{array}{c}\text { Vitamin D } \\
\geq 49.92 \mathrm{nmol} / \mathrm{L} \\
(\mathrm{n}=8)\end{array}$ & $\begin{array}{c}\text { Vitamin D } \\
<49.92 \mathrm{nmol} / \mathrm{L} \\
(\mathrm{n}=42)\end{array}$ & $\mathrm{p}$ \\
\hline $\begin{array}{l}\text { Age (years) } \\
(\text { mean } \pm S D)\end{array}$ & $58.5 \pm 13.5$ & $52.5 \pm 14.5$ & 0.283 \\
\hline \multicolumn{4}{|l|}{ Sex, n (\%) } \\
\hline Female & $2(25.0)$ & $21(50.0)$ & 0.183 \\
\hline Male & $6(75.0)$ & $21(50.0)$ & \\
\hline \multicolumn{4}{|c|}{ Sign and symptoms, n (\%) } \\
\hline Fever & $2(25.0)$ & $28(66.6)$ & 0.047 \\
\hline Dry cough & $5(62.5)$ & $27(64.3)$ & 0.923 \\
\hline $\begin{array}{l}\text { Shortness of } \\
\text { breath }\end{array}$ & $5(62.5)$ & $26(61.9)$ & 0.975 \\
\hline Diarrhea & $0(0)$ & $9(21.4)$ & 0.345 \\
\hline Nausea vomiting & $1(12.5)$ & $14(33.3)$ & 0.239 \\
\hline Headache & $1(12.5)$ & $9(21.4)$ & 0.563 \\
\hline Anosmia & $2(25.0)$ & $8(19.5)$ & 0.700 \\
\hline Hemiparesis & $0(0)$ & $3(7.1)$ & 0.436 \\
\hline Chest pain & $0(0)$ & $4(9.5)$ & 0.363 \\
\hline \multicolumn{4}{|c|}{ Comorbidities, n (\%) } \\
\hline Diabetes mellitus & $5(62.5)$ & $20(47.6)$ & 0.440 \\
\hline Hypertension & $1(12.5)$ & $16(38.1)$ & 0.054 \\
\hline Malignancy & $0(0)$ & $2(4.8)$ & 0.529 \\
\hline $\begin{array}{l}\text { Cardiovascular } \\
\text { disease }\end{array}$ & $1(12.5)$ & $15(35.7)$ & 0.381 \\
\hline $\begin{array}{l}\text { Chronic kidney } \\
\text { disease }\end{array}$ & $2(25.0)$ & $6(14.3)$ & 0.449 \\
\hline HIV infection & $1(25.0)$ & $1(2.4)$ & 0.181 \\
\hline \multicolumn{4}{|l|}{ Admission, n (\%) } \\
\hline Non-ICU & $8(100)$ & $34(80.9)$ & 0.080 \\
\hline ICU & $0(0)$ & $8(19.5)$ & \\
\hline \multicolumn{4}{|c|}{ Thrombosis Manifestations, n (\%) } \\
\hline $\begin{array}{l}\text { Acute coronary } \\
\text { syndrome }\end{array}$ & $0(0)$ & $2(4.8)$ & 0.529 \\
\hline $\begin{array}{l}\text { Cerebrovascular } \\
\text { accident }\end{array}$ & $0(0)$ & $3(7.1)$ & 0.436 \\
\hline $\begin{array}{l}\text { Deep vein } \\
\text { thrombosis }\end{array}$ & $0(0)$ & $1(2.4)$ & 0.659 \\
\hline \multicolumn{4}{|c|}{ In-Hospital Mortality, n (\%) } \\
\hline Survivor & $8(100)$ & $33(78.6)$ & 0.148 \\
\hline Non-survivor & $0(0)$ & $9(21.4)$ & \\
\hline
\end{tabular}


344 Susianti et al.: The role of vitamin D in the COVID-19 associated coagulopathy

Table II Comparison of Laboratory Findings according to Vitamin D Levels.

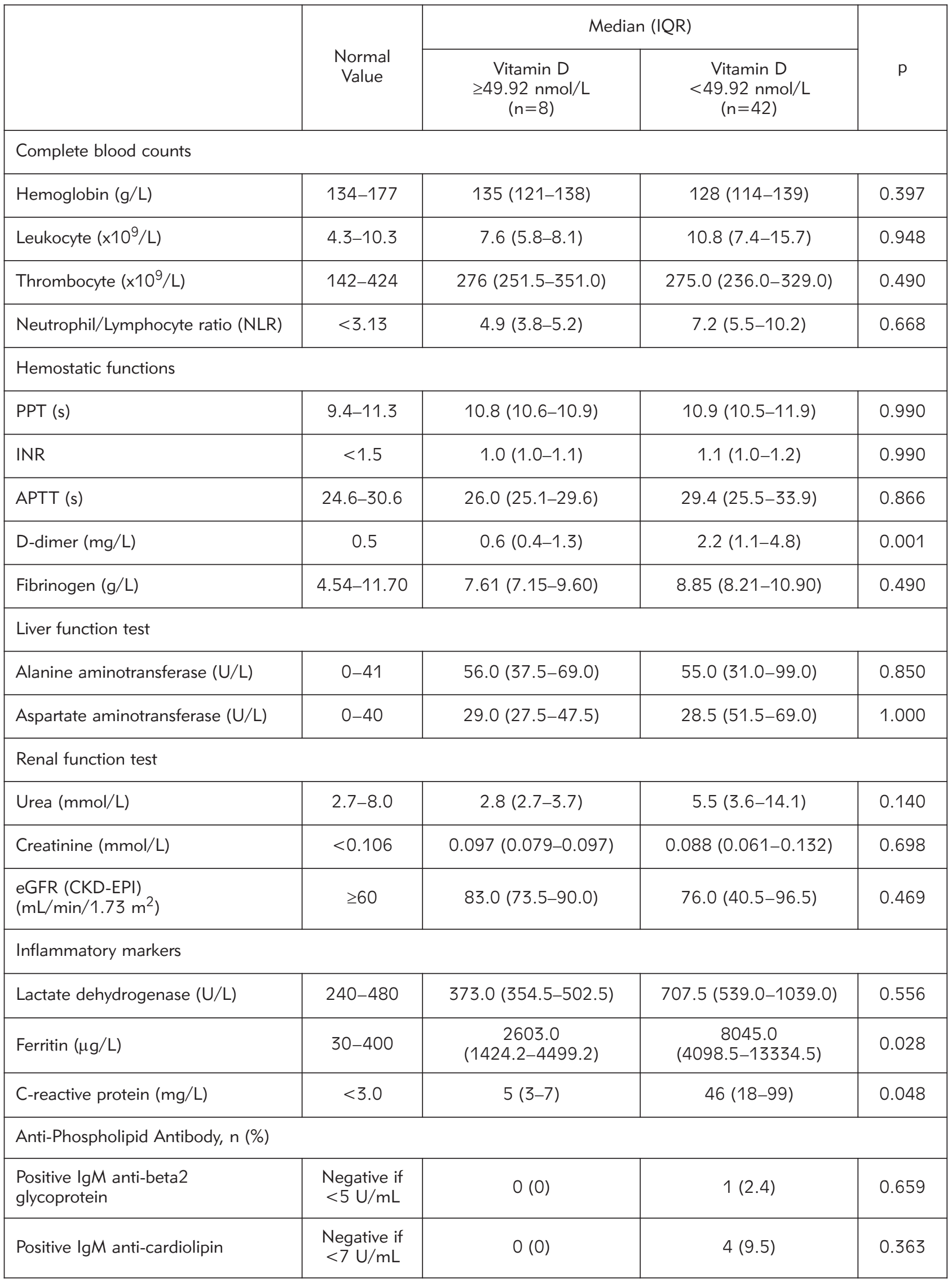


ties between these two groups. According to the sign and symptoms presented at the first time patient came to the hospital, patient with deficient levels of vitamin D had a statistically higher frequency of fever compared to the other group ( $66.6 \%$ vs. $25 \%, p=0.047$ ), yet no other differences were found in the other signs and symptoms between two groups.

There were eight patients admitted to the ICU because of respiratory failure and the need for a ventilator. All of them had low levels of vitamin D $(<49.92 \mathrm{nmol} / \mathrm{L})$; on the other hand, no patient was admitted to ICU from the group of patients with vita$\min D$ levels $\geq 49.92 \mathrm{nmol} / \mathrm{L}(p=0.080)$. We found 6 out of 50 patients (12\%) had thrombosis manifestations: 2 (4\%) had acute coronary syndrome, $3(6 \%)$ had CVA thrombosis, and $1(2 \%)$ had DVT. They were from the groups of patients with vitamin $D$ levels $<49.92 \mathrm{nmol} / \mathrm{L}(p=0.254)$. Among 50 subjects included in this study, nine patients (18\%) died during treatment, and all of them had vitamin D levels $<49.92 \mathrm{nmol} / \mathrm{L}$.

Comparison of laboratory findings of patients according to the vitamin D levels was shown in Table II. There was no statistical difference in the laboratory parameters from complete blood counts, liver, and renal function tests from both groups. Subjects with vitamin D levels $<49.92 \mathrm{nmol} / \mathrm{L}$ had significantly higher D-dimer levels compared to the other group (median 4.4 (2.2-9.8) vs. $1.2(0.8-2.6) \mathrm{mg} \mathrm{FEU} / \mathrm{L}$, $\mathrm{p}=0.001)$, but there is no difference in PPT, INR,
APTT, or fibrinogen levels between these two groups. Patients with vitamin D levels <49.92 nmol/L also showed higher levels of inflammatory markers, such as CRP (median 4.6 (1.8-9.9) vs. 0.5 (0.3-0.7) $\mathrm{mg} / \mathrm{L}, \mathrm{p}=0.048$ ) and Ferritin (median 8045.0 (4098.5-13334.5) vs. 2603.0 (1424.2-4499.2) $\mu \mathrm{g} / \mathrm{L}, \mathrm{p}=0.028$ ) compared to the patients with vitamin D levels $\geq 49.92 \mathrm{nmol} / \mathrm{L}$. However, no statistical difference was shown from LDH between the two groups. Five patients were found to be positive for APL-Abs: 1 (2\%) patient had positive IgM anti-beta2 glycoprotein, and 4 (8\%) patients had positive $\lg M$ anti-cardiolipin. All of them were from the groups of patients with vitamin D levels $<49.92 \mathrm{nmol} / \mathrm{L}$.

\section{Comparison of Vitamin D Levels According to Clinical Status of the COVID-19 Patients}

Patients were grouped according to the severity of coagulopathy and COVID-19 (D-dimer $>2 \mathrm{mg} / \mathrm{L}$, the presence of thrombotic events, ISTH DIC score, ICU admission, and in-hospital mortality). Vitamin D level was compared between these grouped parameters (shown in Figure 1). Patient with D-dimer levels $>2 \mathrm{mg} / \mathrm{L}$ had significantly lower vitamin $D$ levels (median 18.22 (8.74-23.21) vs. 26.71 (16.9753.91), $p=0.006)$. The lower level of vitamin $D$ also showed in the group of patients who developed thrombotic events (median 8.99 (7.74-18.72) vs. 22.21 (15.72-36.19); $p=0.015)$. We also grouped

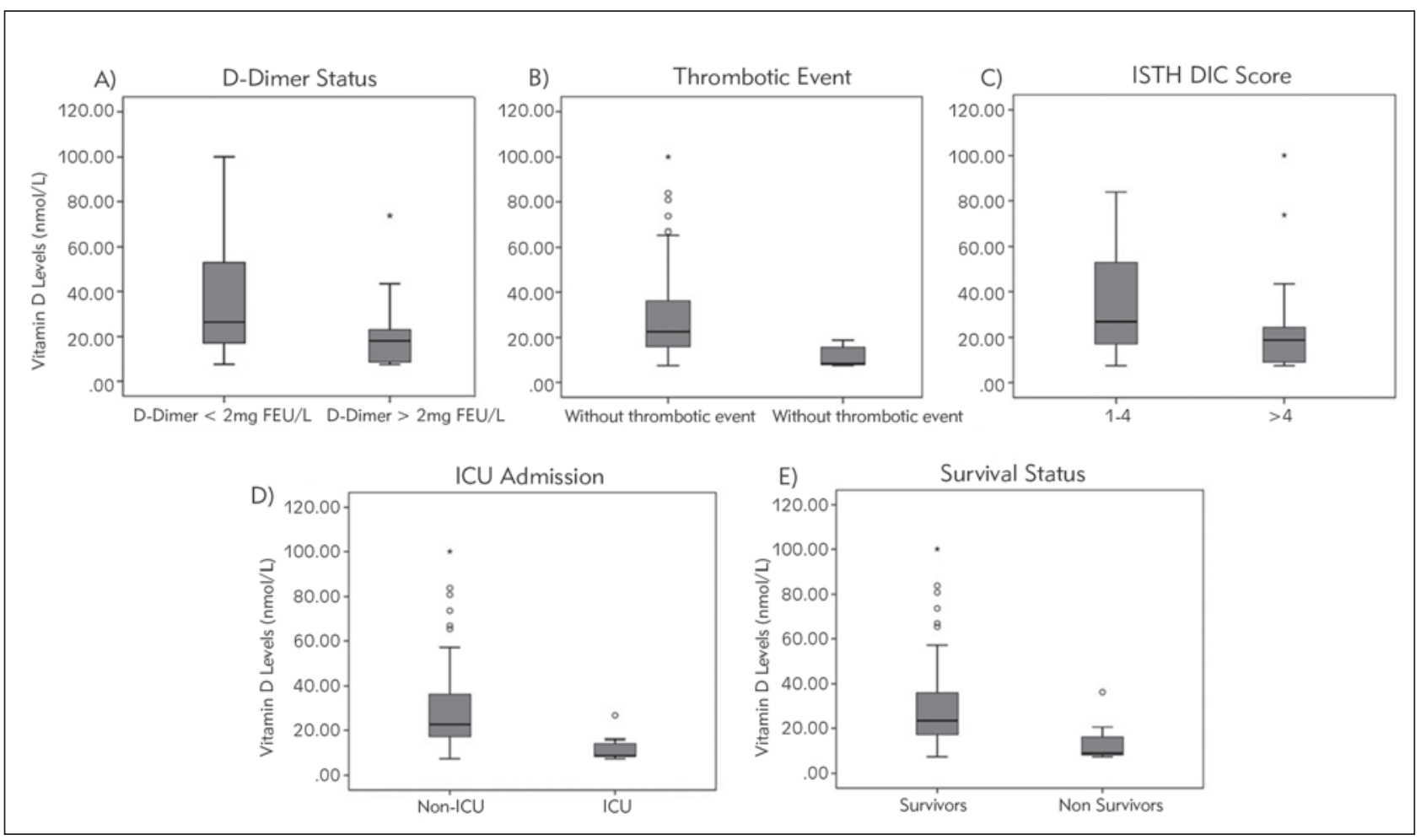

Figure 1 Comparison of Vitamin D Levels According to Clinical Status. 
these patients based on ISTH DIC score; overt DIC was categorized by ISTH DIC score $\geq 5$ based on PPT, thrombocyte, D-dimer, and fibrinogen levels. We found that 29 patients (58\%) had ISTH DIC score $\geq 5$ with significantly lower vitamin $D$ levels (median $18.72(8.99-24.46)$ vs. 26.96 (17.22-52.92), $\mathrm{p}=0.020)$ compared to the patients with ISTH DIC score 1-4. The patients admitted in ICU and those belonging to non-survivor groups of COVID-19 patients also consistently had significantly lower vitamin D levels.
Risk Factors Associated with Coagulopathy among COVID-19 Patients

Clinical manifestations of coagulopathy in COVID-19 were presented as arterial or venous thrombosis as seen in our six patients. However, because of limitations of the numbers who developed the thrombosis, direct analysis for observing factors associated with thrombosis might be inconclusive. Therefore, we analysed the risk of COVID-19 coagulopathy by assessing the increased number of $D$ dimer $(>2 \mathrm{mg} / \mathrm{L}$ ) and ISTH score $\geq 5$. Bivariate and multivariate model analysis for risk factors associated

Table III Factors Affecting the Increase of D-Dimer ( $>2 \mathrm{mg} / \mathrm{L}$ ) from Subjects.

\begin{tabular}{|c|c|c|c|c|}
\hline & \multicolumn{2}{|c|}{ Bivariate Analysis } & \multicolumn{2}{|c|}{ Multivariate Analysis } \\
\hline & OR $(95 \% \mathrm{Cl})$ & $\mathrm{p}$ & OR $(95 \% \mathrm{Cl})$ & $\mathrm{p}$ \\
\hline Age $\geq 60$ years old & $1.3(0.3-3.6)$ & 0.832 & - & - \\
\hline Female & $0.7(0.2-2.2)$ & 0.586 & - & - \\
\hline Diabetes mellitus & $1.4(0.5-4.2)$ & 0.571 & - & - \\
\hline Hypertension & $6.5(1.7-24.6)$ & 0.004 & $0.2(0.1-1.1)$ & 0.067 \\
\hline Cardiovascular disease & $2.4(0.7-8.1)$ & 0.159 & - & - \\
\hline Chronic kidney disease & $1.1(0 .-4.9)$ & 0.902 & - & - \\
\hline Anemia & $1.4(0.4-4.2)$ & 0.571 & - & - \\
\hline Leukocyte $>12.0 \times 10^{9} / \mathrm{L}$ & $2.3(0.7-7.5)$ & 0.164 & - & - \\
\hline Thrombocyte $<150 \times 10^{9} / \mathrm{L}$ & $6.6(0.7-61.1)$ & 0.056 & - & - \\
\hline NLR $>3.13$ & $0.4(0.1-1.4)$ & 0.138 & - & - \\
\hline INR $>1.5$ & $2.3(0.2-26.8)$ & 0.502 & - & - \\
\hline APTT ratio $>1.3$ & $1.6(0.5-5.4)$ & 0.423 & - & - \\
\hline $\mathrm{ALT}>41 \mathrm{U} / \mathrm{L}$ & $1.3(0.4-4.3)$ & 0.641 & - & - \\
\hline $\mathrm{AST}>40 \mathrm{U} / \mathrm{L}$ & $0.5(0.2-1.7)$ & 0.294 & - & - \\
\hline Urea $>8.3 \mathrm{mmol} / \mathrm{L}$ & $8.4(1.9-75.1)$ & 0.023 & $0.4(0.1-3.2)$ & 0.456 \\
\hline Creatinine $>0.106 \mathrm{mmol} / \mathrm{L}$ & $3.0(0.8-11.4)$ & 0.102 & - & - \\
\hline eGFR $<60 \mathrm{~mL} / \mathrm{min} / 1.73 \mathrm{~m}^{2}$ & $3.2(0.6-13.5)$ & 0.103 & - & - \\
\hline $\mathrm{LDH}>480 \mathrm{U} / \mathrm{L}$ & $0.7(0.2-3.1)$ & 0.634 & - & - \\
\hline Ferritin $>400 \mu \mathrm{g} / \mathrm{L}$ & $1.1(0.2-4.9)$ & 0.897 & - & - \\
\hline $\mathrm{CRP}>0.3 \mathrm{mg} / \mathrm{L}$ & $0.8(0.2-3.9)$ & 0.826 & - & - \\
\hline Vitamin $D<49.92 \mathrm{nmol} / \mathrm{L}$ & $6.2(1.1-34.2)$ & 0.021 & $1.8(1.2-4.4)$ & 0.034 \\
\hline Positive IgM anti-cardiolipin & $1.1(0.1-8.4)$ & 0.933 & - & - \\
\hline
\end{tabular}


Table IV Factors Affecting the ISTH DIC Score $\geq 5$ among Subjects.

\begin{tabular}{|c|c|c|}
\hline & \multicolumn{2}{|c|}{ Bivariate Analysis } \\
\hline & OR $(95 \% \mathrm{Cl})$ & $\mathrm{p}$ \\
\hline Age $\geq 60$ years old & $1.2(0.4-3.9)$ & 0.738 \\
\hline Female & $0.8(0.3-2.5)$ & 0.704 \\
\hline Diabetes mellitus & $1.2(0.4-3.6)$ & 0.774 \\
\hline Hypertension & $3.4(0.8-12.8)$ & 0.075 \\
\hline Cardiovascular disease & $3.0(0.8-11.2)$ & 0.095 \\
\hline Chronic kidney disease & $1.3(0.3-5.9)$ & 0.778 \\
\hline Anemia & $1.6(0.5-5.1)$ & 0.567 \\
\hline Leukocyte $>12.0 \times 10^{9} / \mathrm{L}$ & $1.8(0.5-5.9)$ & 0.352 \\
\hline Thrombocyte $<150 \times 10^{9} / \mathrm{L}$ & $4.2(0.4-38.7)$ & 0.380 \\
\hline NLR $>3.13$ & $0.6(0.2-2.4)$ & 0.485 \\
\hline INR $>1.5$ & $0.5(0.4-7.1)$ & 0.128 \\
\hline APTT ratio $>1.3$ & $1.9(0.6-6.8)$ & 0.291 \\
\hline $\mathrm{ALT}>41 \mathrm{U} / \mathrm{L}$ & $2.6(0.8-8.8)$ & 0.142 \\
\hline AST $>40 \mathrm{U} / \mathrm{L}$ & $0.8(0.2-2.5)$ & 0.668 \\
\hline Creatinine $>0.106 \mathrm{mmol} / \mathrm{L}$ & $3.7(0.8-16.4)$ & 0.101 \\
\hline $\mathrm{eGFR}<60 \mathrm{~mL} / \mathrm{min} / 1.73 \mathrm{~m}^{2}$ & $5.0(0.9-27.4)$ & 0.077 \\
\hline $\mathrm{LDH}>480 \mathrm{U} / \mathrm{L}$ & $1.2(0.3-5.6)$ & 0.784 \\
\hline Ferritin $>400 \mu \mathrm{g} / \mathrm{L}$ & $1.8(0.4-8.1)$ & 0.425 \\
\hline$C R P>0.3 \mathrm{mg} / \mathrm{L}$ & $0.7(0.1-3.4)$ & 0.673 \\
\hline Vitamin $D<49.92 \mathrm{nmol} / \mathrm{L}$ & $5.4(1.0-30.2)$ & 0.039 \\
\hline Positive IgM anti-cardiolipin & $2.3(0.2-23.9)$ & 0.473 \\
\hline
\end{tabular}

with increased D-dimer was seen in Table III. In bivariate analysis, hypertension, urea $>8.3 \mathrm{mmol} / \mathrm{L}$, and vitamin D levels $<49.92 \mathrm{nmol} / \mathrm{L}$ were associated with increased D-dimer levels. When these variables were included in the multivariate model analysis, only vitamin D levels were associated with D-dimer increase. The bivariate model for the ISTH DIC score was shown in Table $I V$, and only the vitamin $D$ level was associated with ISTH DIC score $\geq 5$. Because only one variable statistically significant, the multivariate analysis for the ISTH DIC score was not continued.

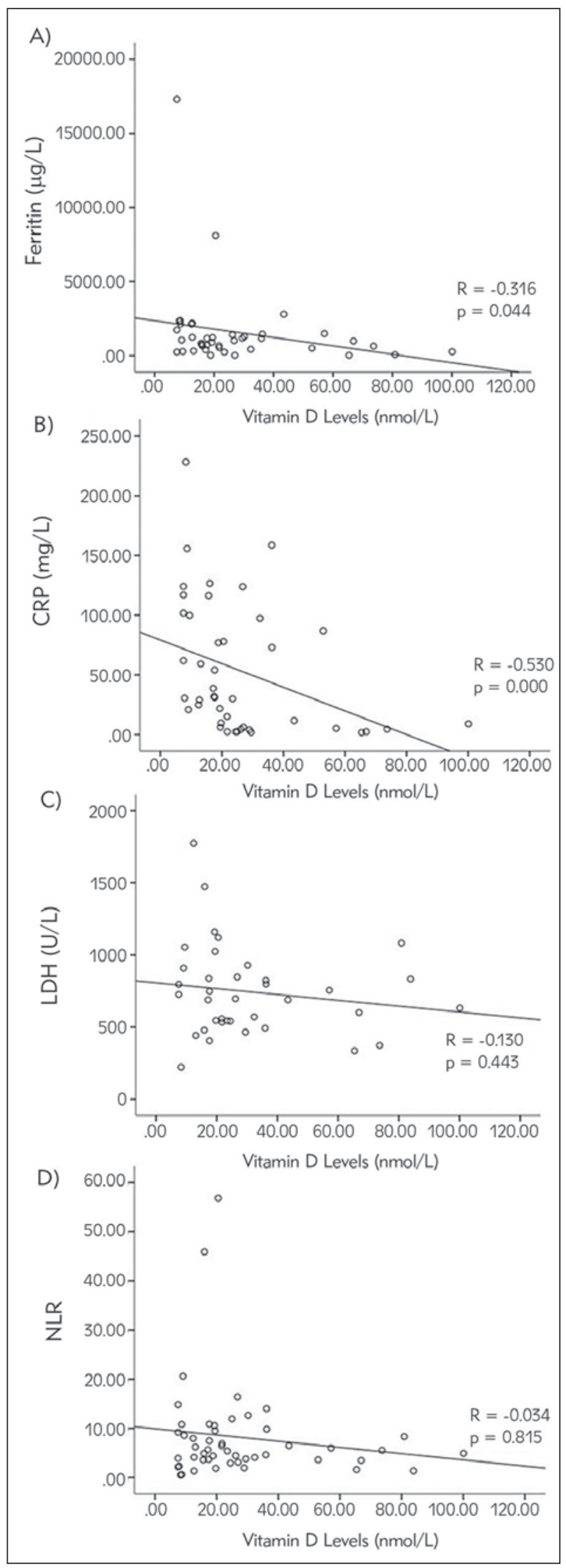

Figure 2 Correlation between Vitamin D Levels and other Inflammatory Markers. 
Correlation of Vitamin D Levels with Other Inflammatory Markers in COVID-19 Patients

To observe the possible mechanisms of low vitamin D levels among COVID-19 patients, the correlation analysis between serum vitamin $D$ levels with other inflammatory markers, such as CRP, ferritin, $\mathrm{LDH}$, and NLR, was also done. Figure 2 showed the correlation analysis between these variables. Ferritin and CRP levels were negatively correlated with vitamin $D$ levels $(R=-0.316, p=0.044$, and $R=-0.530$, $p=0.000$, respectively). On the other hand, $L D H$ and NLR were not correlated statistically $(R=-0.130$, $p=0.443$, and $R=-0.034, p=0.815$, respectively).

\section{Discussion}

The high mortality and its relationship with coagulopathy in COVID-19 have increasingly attracted attention. An increased incidence of arterial or venous thrombosis such as stroke and acute coronary syndromes has been reported in COVID-19 previously $(19,20)$. In this study, among 50 patients confirmed with COVID-19, $12 \%$ of patients developed thrombosis, including DVT, stroke, and acute coronary syndrome. Several mechanisms of COVID-19 coagulopathy have been proposed; one that is exclusively being discussed is the role of vitamin D. Our present study showed that $84 \%$ of hospitalized patients with COVID19 had vitamin $D$ deficiency $(<49.92 \mathrm{nmol} / \mathrm{L})$. Low serum vitamin $D$ levels have also been reported in other viral diseases, such as HIV and hepatitis infections $(21,22)$. Recently, Radujkovic et al. (23) similarly showed that $64 \%$ of patients of COVID-19 had vitamin D levels $<49.92 \mathrm{nmol} / \mathrm{L}$ and were associated with poor prognosis. Carpargano et al. (24) also observed that $81 \%$ of COVID-19 patients with acute respiratory failure treated in ICU had hypovitaminosis $D$.

In our report, a lower level of vitamin $D$ was found in COVID-19 patients with thrombotic events, increased levels of D-dimer, and patients with overt DIC showed by the ISTH DIC score. Vitamin D level $<49.92 \mathrm{nmol} / \mathrm{L}$ was also associated with elevated Ddimer level ( $>2 \mathrm{mg} / \mathrm{L}$ ). ISTH DIC score $\geq 5$ indicated that low vitamin $D$ level was an independent risk factor for the coagulopathy in COVID-19. The role of vitamin $\mathrm{D}$ on the coagulation pathway has been documented before. Khademvatani et al. (13) showed that lower vitamin $D$ level was associated with idiopathic lower-extremity DVT. In a population-based study in Iran, low vitamin D levels were detected in a patient with venous thromboembolism (25). The antithrombotic properties of vitamin $D$ were believed to be through the activation of VDR. VDR knockout mice exhibited an enhanced platelet aggregation and promoted tissue thrombosis (12). Another study also showed that vitamin $D$ could improve endothelial function and reduce the production of proinflammatory cytokines, leading to inhibition of platelet aggregation (26).
The mechanisms of low vitamin D in COVID-19 is still not exact. Lack of published evidence contributes to the difficulty of answering this question. We found that vitamin $D$ level was correlated with the inflammation markers CRP and ferritin. CRP and ferritin are acute phase reactants that have been established to be the biomarkers of hyper inflammation condition in COVID-19 $(27,28)$. The correlation of vitamin $D$ with these markers may explain that inflammatory conditions in COVID-19 can be attributed to the low level of vitamin $D$ in these patients. Hyperinflammation in COVID-19, also described as a cytokine storm, is characterized by increased proinflammatory cytokines, such as IL-6 and TNF- $\alpha$ (29). In another study, Xiong et al. (30) described TNF- $\alpha$ inhibiting the VDR expression in a dose and time-dependent manner on cultured proximal tubular epithelial cells. Meanwhile, Manion et al. (31) showed that deficiency of vitamin D among HIV patients was associated with high IL-6 levels similar to COVID-19.

Although several reports have shown the relationship between vitamin D and coagulopathy, there is still a lack of published data regarding the connection between vitamin D and coagulopathy in COVID19. Besides, there is still a lack of guideline that recommends using vitamin D in COVID-19 until now. The clinical trial for the use of vitamin D supplementation in COVID-19 patients is also still ongoing research. Therefore, this study might help to be a preliminary study to provide a novel insight into the role of vitamin D in the COVID-19 coagulopathy. Our research is still limited to the small population size and restricted only to hospitalized patients. In the future, a multi-centre study with a larger size number or a population-based study can be performed to provide a better result.

In conclusion, we found that most hospitalized patients with confirmed COVID-19 had hypovitaminosis $D$. Deficient levels of vitamin $D$ were independently associated with coagulopathy in COVID-19 patients. Low vitamin $D$ levels might be associated with a hyperinflammatory condition in COVID-19 patients. The role of vitamin D deficiency in COVID19 coagulopathy should be further evaluated and considered as a possible target for intervention.

Acknowledgements. The authors thank all investigators of participating clinicians in Saiful Anwar General Hospital, Malang, Indonesia, who helped in collecting the samples. This study was also supported by the Institute of Research and Community Services, University of Brawijaya by funding this research via Research and Management Development Grants in 2020.

\section{Conflict of interest statement}

All the authors declare that they have no conflict of interest in this work. 


\section{References}

1. WHO Coronavirus Disease (COVID-19) Dashboard. https: //covid19.who.int/ (accessed 29 November 2020).

2. Wang D, Hu B, Hu C, Zhu F, Liu X, Zhang J, et al. Clinical Characteristics of 138 Hospitalized Patients With 2019 Novel Coronavirus-Infected Pneumonia in Wuhan, China. JAMA. 2020 March 17; 323(11): 1061-9.

3. Connors JM, Levy JH. COVID-19 and its implications for thrombosis and anticoagulation. Blood. 2020 June 4; 135(23): 2033-40.

4. Huang C, Wang Y, Li X, Ren L, Zhao J, Hu Y, et al. Clinical features of patients infected with 2019 novel coronavirus in Wuhan, China. Lancet 2020 Feb 15; 395(10223): 497-506

5. Yao Y, Cao J, Wang Q, Shi Q, Liu K, Luo Z, et al. Ddimer as a biomarker for disease severity and mortality in COVID-19 patients: a case control study. J Intensive Care 2020 July 10; 8: 49.

6. Thachil J, Tang N, Gando S, Falanga A, Cattaneo M, Levi $M$, et al. ISTH interim guidance on recognition and management of coagulopathy in COVID-19. J Thromb Haemost 2020 May; 18(5): 1023-6.

7. Ortega-Paz L, Capodanno D, Montalescot G, Angiolillo DJ. COVID-19 Associated Thrombosis and Coagulopathy: Review of the Pathophysiology and Implications for Antithrombotic Management. J Am Heart Assoc 2020 November 24: e019650.

8. Abou-Ismail MY, Diamond A, Kapoor S, Arafah Y, Nayak L. The hypercoagulable state in COVID-19: Incidence, pathophysiology, and management. Thromb Res 2020 Oct; 194: 101-15.

9. Zhang Y, Xiao M, Zhang S, Xia P, Cao W, Jiang W, et al. Coagulopathy and Anti-phospholipid Antibodies in Patients with Covid-19. N Engl J Med 2020 April 23; 382(17): e38.

10. Kabeerdoss J, Danda D. Understanding immunopathological fallout of human coronavirus infections including COVID-19: Will they cross the path of rheumatologists? Int J Rheum Dis 2020 Aug; 23(8): 998-1008.

11. Mohammad S, Mishra A, Ashraf MZ. Emerging Role of Vitamin D and its Associated Molecules in Pathways Related to Pathogenesis of Thrombosis. Biomolecules 2019 Oct 24; 9(11): 649.

12. Aihara K, Azuma H, Akaike M, Ikeda Y, Yamashita M, Sudo $T$, et al. Disruption of nuclear vitamin $D$ receptor gene causes enhanced thrombogenicity in mice. J Biol Chem 2004 August 20; 279(34): 35798-802.

13. Khademvatani K, Seyyed-Mohammadzad MH, Akbari M, Rezaei Y, Eskandari R, Rostamzadeh A. The relationship between vitamin $D$ status and idiopathic lowerextremity deep vein thrombosis. Int J Gen Med 2014 June 19; 7: 303-9.

14. Milinković N, Sarić $M$, Jovičić S, Mirković D, Ležaić $V$, Ignjatović S. Lipid status association with 25-hydroxy vitamin D: Cross sectional study of end stage renal disease patients. J Med Biochem 2020; 39(4): 309-17.

15. Merzon E, Tworowski D, Gorohovski A, Vinker S, Golan Cohen A, Green I, Frenkel-Morgenstern M. Low plasma
$25(\mathrm{OH})$ vitamin D level is associated with increased risk of COVID-19 infection: an Israeli population-based study. FEBS J 2020 July 23: 10.1111/febs.15495.

16. World Health Organization. WHO Covid-19 case definition. Published 7 August 2020. Accessed 1 September 2020. https: //www.who.int/publications/i/item/ WHO-2019-nCoV-Surveillance_Case_Definition2020.1

17. Bouillon R, Carmeliet G. Vitamin D insufficiency: Definition, diagnosis and management. Best Pract Res Clin Endocrinol Metab 2018 Oct; 32(5): 669-84.

18. FB Jr, Toh $\mathrm{CH}$, Hoots WK, Wada $\mathrm{H}$, Levi $M$; Scientific Subcommittee on Disseminated Intravascular Coagulation (DIC) of the International Society on Thrombosis and Haemostasis (ISTH). Towards definition, clinical and laboratory criteria, and a scoring system for disseminated intravascular coagulation. Thromb Haemost 2001 Nov; 86(5): 1327-30.

19. Klok FA, Kruip MJHA, van der Meer NJM, Arbous MS, Gommers DAMPJ, Kant KM, et al. Incidence of thrombotic complications in critically ill ICU patients with COVID-19. Thromb Res 2020 Jul; 191: 145-7.

20. Helms J, Tacquard C, Severac F, Leonard-Lorant I, Ohana $M$, Delabranche $X$, et al. High risk of thrombosis in patients with severe SARS-CoV-2 infection: a multicenter prospective cohort study. Intensive Care Med 2020 Jun; 46(6): 1089-98.

21. Dao CN, Patel P, Overton ET, Rhame F, Pals SL, Johnson $C$, et al. Low vitamin D among HIV-infected adults: prevalence of and risk factors for low vitamin $D$ Levels in a cohort of HIV-infected adults and comparison to prevalence among adults in the US general population. Clin Infect Dis 2011 February 1; 52(3): 396-405.

22. Farnik H, Bojunga J, Berger A, Allwinn R, Waidmann $O$, Kronenberger $B$, et al. Low vitamin $D$ serum concentration is associated with high levels of hepatitis B virus replication in chronically infected patients. Hepatology 2013 Oct; 58(4): 1270-6.

23. Radujkovic A, Hippchen T, Tiwari-Heckler S, Dreher S, Boxberger M, Merle U. Vitamin D Deficiency and Outcome of COVID-19 Patients. Nutrients 2020 Sep 10; 12(9): 2757

24. Carpagnano GE, Di Lecce V, Quaranta VN, Zito A, Buonamico $E$, Capozza $E$, et al. Vitamin D deficiency as a predictor of poor prognosis in patients with acute respiratory failure due to COVID-19. J Endocrinol Invest 2020 August 9: 1-7.

25. Entezari-Maleki T, Hajhossein Talasaz A, Salarifar $M$, Hadjibabaie $M$, Javadi MR, Bozorgi $A$, et al. Plasma Vitamin D Status and Its Correlation with Risk Factors of Thrombosis, P-selectin and hs-CRP Level in Patients with Venous Thromboembolism; the First Study of Iranian Population. Iran J Pharm Res 2014 Winter; 13(1): 319-27.

26. Sultan M, Twito O, Tohami T, Ramati E, Neumark E, Rashid G. Vitamin D diminishes the high platelet aggregation of type 2 diabetes mellitus patients. Platelets. 2019; 30(1): 120-5. 
27. Ahnach M, Zbiri S, Nejjari S, Ousti F, Elkettani C. Creactive protein as an early predictor of COVID-19 severity. J Med Biochem 2020; 39(4): 500-7.

28. Terpos E, Ntanasis-Stathopoulos I, Elalamy I, Kastritis E, Sergentanis TN, Politou M, Psaltopoulou T, Gerotziafas G, Dimopoulos MA. Hematological findings and complications of COVID-19. Am J Hematol 2020 Jul; 95(7): 834-47

29. Mehta P, McAuley DF, Brown M, Sanchez E, Tattersall RS, Manson JJ; HLH Across Speciality Collaboration, UK. COVID-19: consider cytokine storm syndromes and immunosuppression. Lancet 2020 March 28; 395(10229): 1033-4.

30. Xiong M, Gong J, Liu Y, Xiang R, Tan X. Loss of vitamin $D$ receptor in chronic kidney disease: a potential mechanism linking inflammation to epithelial-to-mesenchymal transition. Am J Physiol Renal Physiol 2012 Oct; 303(7): F1107-15.

31. Manion M, Hullsiek KH, Wilson EMP, Rhame F, Kojic E, Gibson $D$, et al. Vitamin D deficiency is associated with IL-6 levels and monocyte activation in HIV-infected persons. PLoS One 2017 May 2; 12(5): e0175517. 